${ }^{11}$ Ibid., note on p. 451. For criticism of other aspects of Kohlberg's theory, see T.M. Reed, "Developmental Moral Theory," Ethics 97 (January, 1987), pp. 441-456.

${ }^{12}$ Lawrence Kohlberg, The Psychology of Moral Development, op. cit., p. 641.

${ }^{13}$ Ibid., p. 645.

${ }^{14}$ Lawrence Kohlberg, "Indoctrination Versus Relativity in Value Education," The Philosophy of Moral Development, op. cit., p. 14.

${ }^{15}$ Ibid., p. 645.

${ }^{16}$ Lawrence Kohlberg, "From 'Is' to 'Ought': How to Commit the Naturalistic Fallacy and Get Away with It in the Study of Moral Development," The Philosophy of Moral Development, op. cit., p. 118.

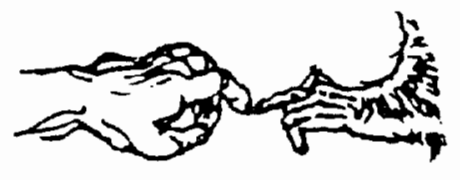

The following prose-poem is written in memory of Paulette Nenner. Paulette was an artist and an animal rights activist. Though neither of us had ever met Dian Fossey, we shared a longstanding admiration for the woman and her work that began for both of us when we first saw those early National Geographic films of Dian interacting with free gorillas, especially with her beloved Digit. Paulette said that someday she wanted to go to Rwanda and help patrol the mountains for poachers. She never made it. She died of pneumonia in March, 1988 in New York City. But I like to think she did at last get to meet her heroine, the woman on the mountain.

- Paulette Callen Nutley, New Jersey

\section{$\underline{\text { A Gorilla In The Mist }}$}

A gorilla stands waiting in the mist. $\mathrm{He}$ is content to wait a long time.

His name...unassuming-from a damaged finger; a shy and gentle being who died with great courage, alone, amid savagery, fighting for his family; and for him, the woman on the mountain grieved and caused a thoughtless world to take note and mark his passing.

She too died, in a way, alone, fighting for her family, amid savagery.

The Cree say that when a human being dies, the soul must stand within a circle of animals - all those one has abused, or killed without need and without respect-in the misty land of the dead, and woe be unto that soul!

It is also said by those who have died and come back that there is, after death, a moving toward a great light, and that along the way one encounters helpers who comfort and encourage us on this journey.

The woman on the mountain...when her turn came...there would have been no circle of animal judges to try her.

She moves toward the light. And out of the mists there steps one to meet her. The one she called Digit. 